\title{
ІНТЕРТЕКСТУАЛЬНІСТЬ ТА ІНТЕРМЕДІАЛЬНІСТЬ
}

УДК 821.111-21 Марло.09

\section{АНТИЧНІ РЕМІНІСЦЕНЦІЇ В ТРАГЕДІЇ КРІСТОФЕРА МАРЛО „ДІДОНА, ЦАРИЦЯ КАРФАГЕНА”}

\author{
Валерія Володимирівна Георгієвська \\ pozitif22@mail.ru \\ Здобувач, асистент \\ Кафедра історії зарубіжної літератури та класичної філології \\ Харківський національний університет імені В. Н. Каразіна \\ Майдан Незалежності 4, 61077, м. Харків, Україна
}

Анотація. Порушується проблема використання античних ремінісценцій у трагедії. Трансформація лірики і драми на основі епосу П. Вергілія допомагає вибудувати трагедію з рисами лірики. Серед інших творів драматурга Дідона - єдиний детально розроблений жіночий образ. Вона, без сумніву, $\epsilon$ центральною фігурою у п’єсі, домінуючи над всіма іншими, в тому числі і над Енеєм. Образ Дідони розкривається в п'єсі через взаємини з Енеєм. Він - ніби погана половина її самою. Їх кохання живе тільки у мріях самої Дідони.

Ключові слова: К. Марло, доба Відродження, трагедія, рецепція.

Аналіз творчості Крістофера Марло привертає увагу до невивченої в українському літературознавстві проблематики творчості англійського письменника, що сприяє кращому розумінню доби Відродження в цілому. У статті порушується проблема аналізу античних ремінсценцій на матеріалі п’єси англійського письменника доби Відродження Крістофера Марло. Досліджуються соціокультурні події доби та їх вплив на драматургію письменника.

Дослідники А. Т. Парфьонов [4], Е. Бартел [5], Д. Коле [6], Дж. Коуп [7], Л. Едінбург [8], С. Мунсон [9], які займалися вивченням творчості письменника, зазначають, що п'єса Крістофера Марло „Дідона, цариця Карфагена” є першим, так би мовити, етюдом драматурга. Під час написання трагедії юний К. Марло ще не віднайшов свого стилю та манери написання, тому мова п'єси, на думку дослідників, ще не досконала. Амбіції спонукали письменника

(C) Георгієвська В., 2013 
порушити кілька проблем у п’єсі, що призвело до негативного результату, і твір письменника пройшов майже не помічено на театральних підмостках ренесансної Англії. Дослідники зазначають, що К. Марло запозичив сюжет із „Енеїди” П. Вергілія.

У статті виявляються ще не досліджені аспекти твору К. Марло „Дідона, цариця Карфагена”, з’ясовується, чим зацікавив письменника образ Дідони та встановлюється своєрідність єдиного детального розробленого жіночого образу у творчому доробку драматурга.

Творчий шлях англійського драматурга, письменника та перекладача Крістофера Марло був надзвичайно коротким. Він прожив лише 29 років, 3 яких 10 років займався літературною діяльністю.

Дослідники Е. Бартел [5], Л. Едінбург [8], С. Мунсон [9] усі твори К. Марло за жанровою своєрідністю відносять до трагедії. А. Т. Парфьонов [4] виділяє риси інших жанрів у деяких творах.

П’єса ,Дідона, цариця Карфагена” написана 1583 р. під час навчання К. Марло в університеті. Вона відповідає традиціям ренесансної драматургії, які увібрали в себе латинські літературні норми та моделі римських п’єс Л. А. Сенеки та $є$ узагальненням щодо давньогрецьких трагедій та міфів про Едіпа, Медею, Геркулеса, падіння Трої тощо. „Енеїда” П. Вергілія, яка була взята за основу сюжету К. Марло, входила до освітянських програм майже в усіх навчальних закладах та стала невід'ємною частиною гуманістичної освіти Англії та Європи у XVI ст.

Різні драматурги в Італії, Франції та Англії адаптували сюжет „Енеїди” П. Вергілія для сцени, і серед них був молодий К. Марло. На відміну від інших п'єс письменника, як свідчать записи, що користувалися значною популярністю, п’єса „Дідона, цариця Карфагена" пройшла відносно непоміченою. Одначе вона виступає показовим прикладом того, як драматична фантазія письменника поєднується з потужним класичним сюжетом [8, с. 80].

Уперше твір опублікований 1594 р., уже після смерті письменника. Ця п'єса контрастує з іншими творами письменника, які ставилися в публічних театрах. На титульному аркуші повідомляється, що вона написана Крістофером Марло та Томасом Нешем і буде ставитися та гратися дітьми 3 каплиці королеви [10, с. 15].

Аналіз тексту виявляе, так би мовити, незрілість техніки написання білого вірша. Наприклад, у ,Трагічній історії доктора Фауста" техніка написання білим віршем на найвищому рівні. Дослідники (А. Т. Парфьонов [4], Е. Бартел [5], Л. Едінбург [8], 
С. Мунсон [9]) прийшли до висновку, що в тексті ,Дідони...” можна виявити ознаки поеми П. Вергілія. Ця п’єса була однією 3 перших робіт письменника та $\epsilon$ прикладом того, як можна за допомогою більш сучасного розміру надати класичному сюжету друге життя, новими костюмами та сценарієм привернути увагу до класичної поеми. „Дідона...” у цьому відношенні більш адаптована для театру, ніж більшість літературних спроб наслідування стилю трагедій Л. А. Сенеки. Більше того, деякі відхилення від фабули П. Вергілія, особливо ті, які сприяють розкриттю можливостей для виявлення характеру і почуттів Дідони, моделі реакцій людини на обставини повторюються і в інших п’єсах К. Марло.

Ренесансні драматурги, інтерпретуючи історію кохання Дідони та Енея, не намагаються закласти основу нового переосмислення класичного сюжету, більшість задовольняються перекладом П. Вергілія, адаптуючи текст поеми під розмір драми. Дві італійські п'єси 1540-х років, одна Джиральді Чінціо, інша Людовіко Дольче, на основі поеми П. Вергілія будують трагедію. Сцени складаються 3 дуже довгих монологів або моральних дебатів між господарями i слугами, перемежовуючись 3 хором та повчальним узагальненням, яке підсумовує самогубство Дідони. Хорові вступи мають явно християнську спрямованість та здаються досить доречними в тексті самих п’єс. Персонажі п'єс шукають розради в любові до Бога, яка є справжнім благом. Але п'єси не можна однозначно віднести за проблематикою до клерикальних. Простежується й антихристиянська, тобто язичницька, спрямованість. Вона виявляється в байках, які підкреслюють жорстокість кохання та фаталістичність влади богів над людством. Гра богів починається 3 довгого монологу Амура, переодягненого Асканієм, який проголошує себе найжорстокішим з богів та закінчує свою промову розповіддю про самогубство Анни (яке надзвичайно засмутило Дідону) і вторгнення Ірбаса до Карфагена [6, с. 47].

У середині XVI ст. у Франції Етьєн Джодель також пише п’єсу за сюжетом поеми П. Вергілія, яка водночас спирається на трагедії Л. А. Сенеки.

Такого роду наслідування відбувається й у часи К. Марло. П'єси за класичними сюжетами ставлять у школах, університетах, у тому числі на юридичному факультеті, а також у колах англійської аристократії. У 1590 році Мері Сидні Герберт, графиня Пемброк, перекладає трагедію „Антонія” Роберта Гарньє з французької, чим спричиняє у своєму придворному колі хвилю копіювань нової 
перекладеної п’єси. Однією 3 таких копій була трагедія Семюеля Деніеля „Клеопатра”, присвячена графині.

К. Марло бачив себе передусім як поетичний драматург 3 гострим почуттям театральних можливостей, тому для „Дідони...” він обрав традиційну літературну форму трагедії - п’ять актів, розділених хоровими інтермедіями, а також максимальну кількість морального коментаря, забезпеченого не тільки хором, але й дебатами. Тематичні можливості руйнівних пристрастей у театрах були очевидні, до того ж сама характеристика гуманістичної трагедії потребувала таких дійств на театральній сцені.

Обставини, в які потрапляє Дідона, та особливе ставлення богів до неї пояснюють ставлення самого письменника. Під час створення цього образу драматург не заглиблюється у психологію Дідони, iі монологи ніколи не зосереджені на собі (вона ніколи не вважала себе зразковою), іiі думки завжди зосереджені на подіях даної хвилини. Крім того, у п’єсі хор не робить жодних висновків щодо дій Дідони. При цьому дія повинна впливати на аудиторію безпосередньо, як відбувається у більшості популярних п’єсах єлизаветинської доби. Відкидаючи конвенції гуманістичної трагедії, К. Марло вибрав театральний спосіб спілкування 3 глядачем, через акценти дії та емблеми як головні сигнали для публіки. Різні дії і тон також відрізняють п’єсу драматурга від „Енеїди” П. Вергілія. Боги й богині у П. Вергілія поводять себе доволі жорстоко та заздрісно по відношенню до людей, що зумовлюється міфами стародавніх греків.

Ще одним нововведенням письменника - спробою Енея піти К. Марло вдалося ускладнити характер героя, а також іронічно поглянути на трагічне кохання. Ця трагедія відрізняється різноманітністю використання пристроїв і реквізитів, зокрема статуї Пріама, портретної галереї женихів Дідони, снастей конфіскованих суден, які стають об’єктом скарг Дідони.

Комічних сцен у гуманістичній трагедії не було, але в менш формальних ii зображеннях вони були доволі частими. Комічні сцени з'являються в усіх п'єсах К. Марло, за винятком „Едуарда II”. Включенням елементів комедії до своїх творів письменник забезпечував комерційний успіх трагедій і відповідав загальним традиціям того часу.

Комічне особливо проявляється в персонажа Ганімеда, яку виконував хлопчик, а не дорослий актор. Його простодушні вчинки та реакція на коштовні подарунки Юпітера $є$ тому підтвердженням: „Я б взяв коштовність для мого вуха, / I чарівну брошку для капелюха, / І тоді я буду обійматися з вами сто разів" [10, с. 70-71]. 
Саме час поставити питання, на що спрямований цей акцент (персонаж Ганімеда). Як відомо, всі ролі у п’єсі виконували хлопчики і такий акцент на дитячих якостях та безпосередності Ганімеда створював ілюзію, що інші ролі виконували дорослі актори, або він був спрямований на підкреслення того, що всі ролі (жіночі та чоловічі) виконують діти.

Цікаво, як К. Марло паралельно ,залицяльній” риториці Юпітера та Венери будує їх взаємодію із хлопчиком, надаючи сцені настрій аналогічний спілкуванню Дідони та Енея. Юпітер та Венера заманюють хлопчика подарунками, солодощами: „Давай жити разом зі мною і моєю любов'ю...” (Звернення Юпітера, по суті, закінчується фразою: „Якщо хочеш бути моїм коханням”). Подарунки Венери та сестри сприймаються нормально. Але ті, що пропонує Юпітер, як знак своїй влади, означають шкоду або збитки для інших. Усе це призводить до зниження образу бога та протиставлення його простим людям. Але між цими сценами є ще один символічний подарунок від Дідони Енею після закінчення полювання: „Статут любові, в моїй зброї для твоєї Італії, / Правління якої на твоїх плечах; / . . Тримай, візьми ці коштовності 3 моєї руки, / Ці золоті браслети, і цю обручку, / I будь ти король Лівії, / Ось тобі мій подарунок” [10, с. 81].

Такий подарунок Дідони не був зрадою колишньому чоловіку Сикхею, а лише був проявом іiі відданості новому чоловіку.

Письменник у п'єсі неодноразово підкреслює моральну відмінність Юпітера та турботливої жінки (Дідони), надаючи перевагу останній. Юпітер клеїть дурня у проявах свого кохання. Дідона, вражена стрілою Купідона, більш щиро виражає своє кохання. Вона стає трагічною жертвою стріли Купідона, але не іï абсурдним прикладом. П’єса К. Марло - гра контрастів трагічного та комічного.

Письменник залишився досить близьким до поеми П. Вергілія, але не намагається змінити їх відповідно до сенеківської конвенції. Він не вдався до використання партій хору із трагічною риторикою в кінці кожного акту, пов'язаних 3 міфологічним підземним світом, щоб зобразити смуток чи гнів. У трагедії $\epsilon$ один епізод, де письменник дозволив собі все ж таки наблизитися за характером п’єси до трагедій Л. А. Сенеки. У міфі про падіння Трої, порівняно 3 П. Вергілієм, є певні нововведення: сцена благання старого Пріама Енеєм, що відображає сенеківську схильність до гротескних деталей. Крім того, К. Марло не використовує богів для відправлення Енея до Італії. Готуючи корабель до негайного відплиття, Еней ні на хвилину не згадує Дідону, не намагається 
проститися 3 нею, порушуючи закони любові: „Я не можу Дюре, прощатися із жінкою важко. / До моря, Еней, до Італії!” [10, с. 95].

Детальний аналіз зародження почуттів між Енеєм та Дідоною має велике значення у виявленні того, що саме хотів підкреслити письменник в їх коханні.

У цьому відчувається внутрішня спокуслива сила любові, яка була поставлена в несприятливі життєві умови. Поранення Дідони Амуром і іiї залицяння до Енея у печері, ніякові одкровення Дідони щодо своїх нових бажань, які Амур таємно їй навіяв, боротьба 3 ними, - усе це має присмак нездійсненного завдання i комедії перебільшених ролей.

Під час повернення разом із Анною з корабля Еней чує від Дідони докори: „Це твоя любов до мене?”. Еней непереконливо виправдовується і вона йому все пробачає доволі швидко: ,Любов змусила мене ревнувати, але загладити свою провину, / Можу імператорською короною з Лівії, / Бери Пунічний скіпетр замість мене / I покарай мене, Енеє, за цей злочин" [10, с. 91-92].

Коли натовп висловлює невдоволення щодо коронування Енея, письменник вводить влучне порівняння Енея та Юпітера, яке переконує людей. „... Тепер виглядає як безсмертний Юпітер Еней: / О де ж Ганімед і Меркурій, щоб підняти кухоль?... / Десять тисяч Амурів зависли в повітрі / I роздивляються прекрасне обличчя Енея!" [10, с. 89-90].

Слова, сказані Дідоною як комплімент, ставляться глядачами під сумнів і посилюють негативне та іронічне сприйняття Енея. Крім того, Амур у п’єсі переслідує Дідону та навіює їй різні думки, тому їх захоплення зовнішністю Енея $є$ не чим іншим, як іронією. Коханий Дідони сприймає іï слова прохолодно, чим ще більше руйнує класичний образ закоханого.

Під час наступної зустрічі Дідона висловлює свій захват їх романтичною близькістю: „...Про те, що хмари тут літають, / Як ти і я вони не можуть хизуватися собою! / Небо заздрить нашій радості, стає восково-блідим, / I коли ми пошепки розмовляємо, то зірки падають, / Щоб бути учасниками нашої медової розмови” [10, с. 84].

Натяк на хмари, імовірно, апелює до „Енеїди” П. Вергілія. До сцени, в якій Венера сховала Енея у хмарах, щоб благополучно доправити його до Карфагена. Дідона К. Марло відчайдушно прагне залишитися наодинці 3 Енеєм. Ії слова творять чудо та небеса поступаються i сприяють їх близькості. Уміння письменника модулювати та передбачати реакцію читача та глядача не може не вражати. 
Коли Дідона отримує звістку про від'їзд Енея, вона каже: „Вернись, вернись! /...І дозвольте мені прив'язати своє тіло до твого, / Таким чином ми зможемо бути нерозлучними, / Ми зможемо бути як один парус в Італії” [10, с. 105].

Як відомо, К. Марло перекладав „Метаморфози” П. Овідія під час навчання в університеті. I саме елегії П. Овідія були джерелом еротизму у трагедії „Дідона цариця Карфагена”. Драматург робить спробу виокремити, пояснити та зобразити чоловіче та жіноче сприйняття сексу. Дідона, на відміну від Енея, ладна проміняти всі багатства світу на кохання та плотські втіхи. Еней теж не відмовляється прямо від кохання та близькості з Дідоною, але віддає перевагу висловленню почуттів словами, а не ділом: „О, Дідона, покровителька всіх наших життів, / Коли я залишу тебе, смерть буде моїм покарання! / Чудово, що вирує море, показуючи невдоволення норовливої долі, / Удар вітру погрожує, а ви, скелі і піщані насипи! Це порт, який прагне завоювати Еней” [10, с. 108].

Кохання між Дідоною та Енеєм пронизане самообманом. Кожен із них заглиблюється у свої почуття та не звертає увагу на іншого. Звісно, вони кохають одне одного, але егоїзм не дає їм розчинитися у почуттях та забути власні амбіції.

К. Марло наділяє Дідону більшим творчим діапазоном, ніж Енея, із практичним передбачення подій однією та галюцинаційним виконанням бажань іншого. Після того як вона дарує корону Енею, він отримує титул і владу, а ії переповнюють побоювання та ревнощі. Ïї початковий емоційний відгук на ситуацію є результатом виконаного бажання та еротичних фантазій. К. Марло повертає іiі до дійсності, змушуючи концентруватися на реальних подіях, щоб зберегти кохання: „....В мене була чарівна сила вітру. / Щоб створити золоту кулю, / Етруське море було в моїх руках, / Він міг страждати на моїх грудях. / Як же часто він намагається підняти вітрила і піти! / Я повинна перешкодити йому, / Бажаючи служити, не буду” [10, с. 104].

Вона наказує взяти його сина Асканія заручником, конфіскувати з суден вітрила, щоб Еней не міг піти від неї або навіть спалити їх (Асканій буде повернений із полону Гермесом безпосередньо Енею). У той же час його суперник за кохання Дідони - Ірбас - всіляко сприяє від'їзду Енея та готовий замінити його в серці Дідони. Але цариця пов'язує своє щастя та подальше життя, не без участі богів, тільки з Енеєм, зазначаючи: „Якщо він не покине мене, я ніколи не помру, / Бо в його зовнішності я бачу вічність, / І він зробить мене безсмертною поцілунком" [10, с. 94]. 
Гіпербола, 3 еротичним підтекстом, зливається 3 одним із іiі пророчих знань, що вона неодмінно помре в результаті його відмови.

Знову ж таки К. Марло зображує Дідону, за характером ближчу до елегій П. Овідія, ніж до поеми П. Вергілія, передаючи іiі основне небажання засудити його або спрямувати свій гнів проти нього. Аналізуючи іï почуття до Енея, стає зрозуміло, що ii готовність віддати чоловіку все, іронічна відмова аналізувати й усвідомлювати свої помилки та абсолютна відданість знищують іiі.

Дідона К. Марло залишається більш уразливою, ніж Дідона в поемі П. Вергілія. Коли терпець їй увірвався, вона впадає у відчай та лють, але потім змінює гнів на милість: „...Чому ти кажеш таке мені в обличчя? / Якщо хочеш залишитися, стрибай у мої обійми. / Руки мої широко відкриті. / Якщо ні, якщо ти відвернувся від мене, i я відвернуся від тебе, / Бо ти бажаєш попрощатися, / У мене немає влади, щоб утримати тебе" [10, с. 102].

Після того як Еней все ж таки залишає їі, вона повертається ще раз, щоб збагнути його відсутність: „Він пішов? / Так, але він повернеться, він не може піти назавжди, / Він любить мене занадто сильно, щоб так вчинити" [10, с. 105].

Ïї гнів поступається відчаю. Драматург уводить швидке чергування відчаю та надії, остання 3 яких дрейфує в галюцинаторному режимі, що призводить Дідону до дезорієнтації. Вона сприймає рибалку за Енея та радо вітає його: „Але він повертається назад, до мене, / Повертається стрімголов: ласкаво просимо, любове моя!" [10, с. 109-110].

Дідона кидається до нього, щоб радо зустріти його, але раптом розуміє свою помилку: „А де ж Еней! / Ax, він пішов, він пішов!"’ [10, с. 109-110].

У всіх жестах, вчинках, словах Дідони простежується відмова від реальності. Вона відчайдушно намагається жити минулим. Така поведінка повільно наближає іiі до єдиного, як їй здається, правильного рішення - самогубства.

Мрії Дідони романтичні, інколи еротичні, пов'язані з Енеєм: „Залийте мені крила воском, як Ікару, / I над його кораблем буду простувати я до сонця. / Крила можуть розплавитися і я впаду на його руки, / Або я умовлю хвилі, щоб я могла доплисти до нього, як племінниця Тритон... / Або я можу покликати дельфінів / Та на їх спинах їздити до мого коханого... / О, Нептуне, Юпітере, збережіть кохання Енея до Дідони!” [10, с. 84-85].

Дідона балансує на межі божевілля, серед іï ірраціональних марень будуть два пророчих прокляття майбутнього Риму та 
Карфагена. Вже перед самою смертю цариця все ж не може побажати смерті своєму коханому: „Живи, коханий Енею! / Справжня Дідона помирає” [10, с. 109-110]. Така кінцівка більш наближена до Дідони П. Овідія, ніж до П. Вергілія.

Іронія свідомого самознищення змішується в останній момент iз парадоксальним бажанням контролювати свою долю. На відміну від античних трагедій, де чітко простежувався вплив фатуму, у трагедії К. Марло персонаж сам впливає на власну долю. Для Дідони краще погубитися, ніж чекати та терпіти примхи долі.

Самогубство Дідони зумовлене прагненням письменника вразити та здивувати глядача. Скоріш за все, під час самогубства актор, який виконував роль Дідони, падав до люку за штучним полум'ям, імітуючи спалення. Такий прийом дозволив іронічно підійти до сцени смерті Дідони. Про це свідчить і ії останній монолог: „....Людина, яку я кохала, покинула мене... / Любов його як полум'я вогню. / Прометей має надіти форму Амура, / І я повинна загинути від його зброї. / Енею, о Енею, вгамуй це полум'я!” [10, с. 109-110].

Така тема любов-самогубство продовжується в долі кохання Анни та Ірбаса, які ніби сліпі кошенята йшли слідами Дідони та Енея.

Отже, Дідона залишається єдиним детально розробленим жіночим образом протягом усієї кар'єри драматурга. Вона, без сумніву, є центральною фігурою у п'єсі, домінуючи над всіма іншими, в тому числі й над Енеєм. К. Марло заглибився в розробку образу Дідони. Її моральні негаразди домінують у п’єсі. Написання п’єси, у якій головна роль - жіноча, було досить ризикованим. Решта п’єс драматурга знайшли свого читача та глядача, „Дідона, цариця Карфагена" була найменш популярною серед творчого доробку письменника.

Ця трагедія не зводиться до морального кліше - жадання призводить до загибелі. П'єса насправді не про пристрасті, хіть або вплив жорстокої долі і богів на невинних людей.

У концепції трагедії К. Марло всі дійові особи пов'язані одне 3 одним. Не менш важлива техніка подвійного сприйняття дійових осіб. Подвійне сприйняття Дідони спонукає до суперечливої оцінки подій та має перспективи для театральної постановки. Один аспект сприйняття випливає з реплік персонажа, інший глядач бачить, коли хтось (інша дійова особа) вказує на суперечливість почуттів чи вчинків персонажа.

Подальший науковий пошук може відбуватися в дослідженні образу Дідони та трансформації жанру. 
1. Галич O. Теорія літератури : [підручник] / О. Галич, В. Назарець, Є. Васильєв - К. : Либідь, 2008. - 488с.

2. Літературознача енциклопедія : у 2 т. / [авт.-уклад. Ю. І. Ковалів].- К. : ВЦ „Академія”, 2007. - Т. 1. - 608 с.

3. Літературознача енциклопедія : у 2 т. / [авт.-уклад. Ю. І. Ковалів].- К. : ВЦ „Академія”, 2007. - Т. 2. - 624c.

4. Парфенов А. T. Кристофер Марло / Александр Тихонович Парфенов. М. : Худож. лит., 1964. - 221 с.

5. Bartel E. Critical Essays on Christopher Marlow / Emily Bartel. - New York : Twayne Press, 1997. - 240 p.

6. Cole D. Christopher Marlowe and the Renaissance Tragedy / Douglas Cole. London : Cambridge University Press, 1995. - 119 p.

7. Cope J. I. Marlowe's Dido and the Titillating Children / Jackson I. Cole. London : English Literary Renaissance, 1974. - 325 p.

8. Edinburg L. Christopher Marlowe, Renaissance Dramatist / Lisa Edinburgh. London : University Press, 2008. - 179 p.

9. Munson S. Sex, Gender, and Desire in the Plays of Christopher Marlowe / Sara Munson. - London : University of Delaware Press, 1998. - 210 p.

10. The Complete Works of Christopher Marlowe: All Ovid's Elegies, Lucan's First Book, Dido Queen of Carthage, Hero and Leander, Vol. I. - London : Benediction Classics, 2012. - 274 p.

\section{АНТИЧНЫЕ РЕЦЕПЦИИ В ТРАГЕДИИ КРИСТОФЕРА МАРЛО ,ДИДОНА, ЦАРИЦА КАРФАГЕНА"}

\section{Валерия Владимировна Георгиевская pozitif22@mail.ru \\ Соискатель, ассистент}

Кафедра истории зарубежной литературы и классической филологии Харьковский национальный университет имени В. Н. Каразина Площадь Свободыл, 4, 61077, г. Харьков, Украина

Аннотация. Поднимается проблема использования античных реминисценций в трагедии. Трансформация лирики и драмы на основе эпоса П. Вергилия помогает выстроить трагедию с чертами лирики. Среди других произведений драматурга Дидона - единственный детально разработанный женский образ. Она, несомненно, является центральной фигурой в пьесе, доминируя над всеми другими, в том числе и над Энеем. Образ Дидоны раскрывается в пьесе посредством взаимоотношений с Энеем. Он - словно плохая половина ее самой. Их любовь живет только в мечтах самой Дидоны.

Ключевые слова: К. Марло, эпоха Возрождения, трагедия, рецепция.

$$
\text { RECEPTION IN THE ANCIENT TRAGEDY }
$$

OF CHRISTOPHER MARLOWE "DIDO, QUEEN OF CARTHAGE"

\section{Valeriya Georgievskaya pozitif22@mail.ru}

Department of history of foreign literature and classical philology

V. N. Karazin Kharkiv National University

Freedom Square 4, 61077, Kharkov, Ukraine 
Abstract. Analysis of Christopher Marlowe's works highlights unexplored issues in Ukrainian literary English writer, contributing to a better understanding of the Renaissance in general. The article touches classical receptions problem analysis based on the play by the writer in the Renaissance. Investigates the socio-cultural events of the day and their impact on drama writer. In this article are not researching aspects of C. Marlowe "Dido, Queen of Carthage", it appears more interested in the writer's image of Dido and installed originality single elaborate female image artistically playwright. The play "Dido, Queen of Carthage" was written in 1583 while studying at the University of C. Marlowe. It corresponds to the tradition of Renaissance drama, which absorbed at Latin literary norms and models of Roman plays L. A. Seneca and is a generalization about the ancient Greek tragedies and myths of Oedipus, Medea, Hercules, the fall of Troy and others. "Aeneid" by P. Virgil, who was taken based on plot C. Marlowe, was part of educational programs in almost all schools and became an integral part of humanistic education in England and Europe in the XVI century. So, Dido is the only elaborate images of women throughout their careers playwright. It is, without doubt, is the central figure in the play, dominating over all others, including the above Aeneas. C. Marlowe absorbed in developing the image of Dido. Her moral problems dominate the play.

Key words: C. Marlowe, the Renaissance, the tragedy, reception.

\section{References}

1. Halych O., Nazarets' V., Vasyl'iev Ie. Teoriia literatury [Theory of the literature]. Kyiv, 2008, 488 p. (in Ukrainian).

2. Kovaliv Iu. I. Literaturoznacha entsyklopediia [Literary encyclopedia]. Kyiv, 2007, vol. 1, 608 p. (in Ukrainian).

3. Kovaliv Iu. I. Literaturoznacha entsyklopediia [Literary encyclopedia]. Kyiv, 2007, vol. 2, 624 p. (in Ukrainian).

4. Parfenov A. T. Kristofer Marlo [Christopher Marlowe]. Moscow, 1964, 221 p. (in Russian).

5. Bartel E. Critical Essays on Christopher. New York, 1997, 240 p.

6. Cole D. Christopher Marlowe and the Renaissance Tragedy. London, 1995, 119 p.

7. Cope J. I. Marlowe's Dido and the Titillating Children. London, 1974, 325 p.

8. Edinburg L. Christopher Marlowe, Renaissance Dramatist. London, 2008, $179 \mathrm{p}$.

9. Munson S. Sex, Gender, and Desire in the Plays of Christopher Marlowe. London, 1998, $210 \mathrm{p}$.

10. The Complete Works of Christopher Marlowe: All Ovid's Elegies, Lucan's First Book, Dido Queen of Carthage, Hero and Leander, London, 2012, vol. I, $274 \mathrm{p}$.

\section{Suggested citation}

Georgievskaya V. Antychni reministsentsiï v trahediï Kristofera Marlo "Didona, tsarytsia Karfahena" [Antique reminiscences in the tragedy "Dido, Queen of Carthage" by Christopher Marlowe]. Pytannia literaturoznavstva, 2013, no. 88, pp. 318-328. (in Ukrainian). 